\title{
Soil Attributes in Anthropized Hygrophilous Forest in Northern Minas Gerais State, Brazil
}

\author{
Maria das Dores Magalhães Veloso ${ }^{1}$, Luiz Arnaldo Fernandes ${ }^{2}$, Marly Antonielle de Ávila ${ }^{3}$, Yule Roberta Ferreira \\ Nunes ${ }^{1}$ and Leidivan Almeida Frazão ${ }^{2}$ \\ 1. Universidade Estadual de Montes Claros, Montes Claros, Minas Gerais State 39401-089, Brazil \\ 2. Instituto de Ciências Agrárias, Universidade Federal de Minas Gerais, Montes Claros, Minas Gerais State 39404547, Brazil \\ 3. Universidade Federal de Lavras, Lavras, Minas Gerais State 37200-000, Brazil
}

\begin{abstract}
The soils of Brazilian Cerrado are characterized with high acidity and low fertility and productivity. However, these attributes are not homogeneously distributed through all phytophysiognomies of this biome, and wetland known as palm swamp or "veredas" are an exception. This study aimed to describe and compare the chemical and physical attributes of soil surface layers at six palm swamps areas under different anthropization processes in the northern region of Minas Gerais state, Brazil. Soil sampling of different hydromorphic soils were collected at 0-20 cm depth layer from $100 \mathrm{~m}^{2}$ plots in the studied areas. The variables were compared using the GLM procedure of ANOVA using Statistica 10 software. Soil chemical attributes and similarities between the six palm swamps areas were compared using the statistical software R. Soil chemical attributes were different and soil physical attributes were similar between the evaluated areas. The similarities among the attributes were classified into three groups according to the anthropic pressures, as well as with the origin of the soil material in the six palm swamps areas evaluated. It could be concluded that soil fertility can be reduced in palm swamps that suffered greater anthropic intervention. The three similarity groups might be associated not only to the anthropic pressures, but also to the raw material of soil at the six palm swamps areas evaluated.
\end{abstract}

Key words: Hydromorphic soils, palm swamps, soil fertility.

\section{Introduction}

Naturally, Cerrado soils have high acidity and low fertility and productivity [1], but these features are not homogenously distributed. Cerrado biome covers approximately $25 \%$ of Brazilian surface area and shelters several phytophysiognomies within the biome $[1,2]$. Two distinct habitats, akin to differentiated ecosystems, are related through edaphic and topographic factors in addition to fire and anthropization processes [3].

In order to attend the demand for food and fiber, the expansion of agricultural areas and forestry plantations in Brazil during the 1970s, large areas of Cerrado were considered new agricultural lands [2, 4].

Corresponding author: Leidivan Almeida Frazão, professor, research fields: soil science, dynamic of soil organic matter, management of agrosilvopastoral and agroforestry systems.
Among these areas, those located next to bodies of water and seasonally flooded environments became priority areas for monoculture, since water is a facilitating factor for the development of agriculture and livestock. Areas of Cerrado located in wetlands, known as palm swamps or "veredas", became part of these priority areas, since these environments have fertile soil and large groundwater reservoirs that merge into a central channel [5].

"Vereda", or hygrophilous forest, is a denomination given to one phytophysiognomy present in the Cerrado, according to Boaventura [6] and Tubelis [7], usually presents peaty and shallow soils, with a sandy surface layer, clayey subsurface layer and high hydric saturation. These environments have low resilience and are sensitive to anthropic pressures, once the changes into surrounding areas can promote a gradual loss of their intrinsic characteristics [8]. 
Despite the dominance of Oxisols in Cerrado biome, the main classes of soils in palm swamps are Histosols, Udox and Aquoll [6]. These soils, with low material deposition and high levels of organic material and humidity, are sensitive to anthropic interference. According to Santos and Salcedo [9], lowland soil has higher levels of organic material than upland soil. As these environments are very vulnerable to perturbations, the soil fertility of surface layers can change significantly due to anthropic modifications.

The intensive use of soils and the reduction or removal of native vegetation can result in reduction of soil fertility [10, 11]. According to Perin et al. [12], agricultural cultivation reduces the level of soil organic material due to increased decomposition of plant litter. These authors also observed that soil disturbance with conventional tillage leads to decrease in organic material, reducing the soil fertility and contributing to the occurrence of soil erosion.

Thus, the aim of this work was to characterize and compare the soil's chemical and physical attributes in the surface layer of six palm swamps areas under different levels of anthropization in the Pandeiros river basin located at Northern Minas Gerais state, Brazil.

\section{Materials and Methods}

This work was performed in six palm swamps areas located at the municipalities of Bonito de Minas and Januária, in the region of the upper-middle Pandeiros river, a tributary of São Francisco river, in northern of Minas Gerais state, Brazil. The palm swamps areas are

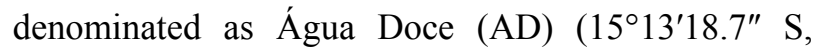

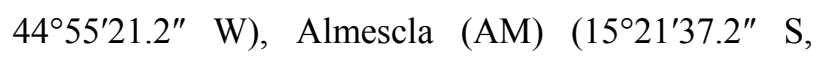

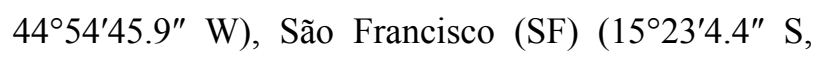

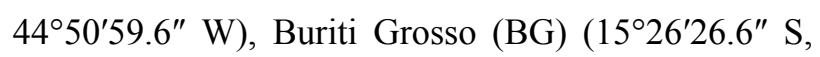
45 $\left.3^{\prime} 55^{\prime \prime} \mathrm{W}\right)$, Capivara (CP) $\left(15^{\circ} 16^{\prime} 10.23^{\prime \prime} \mathrm{S}\right.$, $\left.44^{\circ} 51^{\prime} 13.6^{\prime \prime} \mathrm{W}\right)$ and Pindaibal (PI) $\left(15^{\circ} 22^{\prime} 30.2^{\prime \prime} \mathrm{S}\right.$, $\left.45^{\circ} 2^{\prime} 0.17^{\prime \prime} \mathrm{W}\right)$ (Fig. 1).

In the $\mathrm{AD}$ palm swamp, Histosol was found at the left bank, and Aquoll was observed at the right hand side bank. In the $\mathrm{SF}$ and $\mathrm{CP}$ the Aquoll soil was observed, and in the AM, BG, and PI the Histosol was observed. For all evaluated areas, the soil had a sandy texture and flat relief. AD and SF palm swamps are located in areas that contain rocky outcrops.

In the six selected areas, $\mathrm{AD}, \mathrm{AM}$ and $\mathrm{SF}$ are visually preserved; at the edges and in the interior, only small areas are occupied by familiar agricultural activities, with no record of large deforestation, fires or the remnants of enterprise. Thus, these palm swamps areas are preserved when compared with the other palm swamps in this study. At the palm swamps BG, CP and PI, the opposite fate is observed, particularly for BG and its surroundings, which suffered a suppression of $99.9 \%$ of vegetation when replaced by a monoculture of irrigated rice in the early 1970s [13], with a concomitant opening of drainage ditches to allow the flow of water and maintenance of soil humidity. These impacts were exacerbated by a planted monoculture of eucalyptus that surrounded the palm swamp area.

At the end of the 1970s, both the palm swamps and Cerrado were abandoned. As consequence of anthropic impacts suffered over the years, BG was invaded by a single species of Poaceae, rich in biomass, leaving this area vulnerable to constant fires and potential impoverishment of the ecosystem. The palm swamp was gradually but severely degraded, with the disappearance of typical species and the invasion of Cerrado species. As a result, BG palm swamp, which naturally occupied an area of 350 ha, now is restricted to approximately $5 \%$ of its original area and no longer shows the characteristics of other palm swamps areas in the region. Water storage happens only at the rainy season, with a flow rate of $207 \mathrm{~L} / \mathrm{s}$ and a 100\% reduction during the dry season [13].

The palm swamps evaluated in this study have shown variation in their conservation condition, mainly in the amount of water and size of vegetation. At $\mathrm{AD}$, water is present year-round, the tree covers 


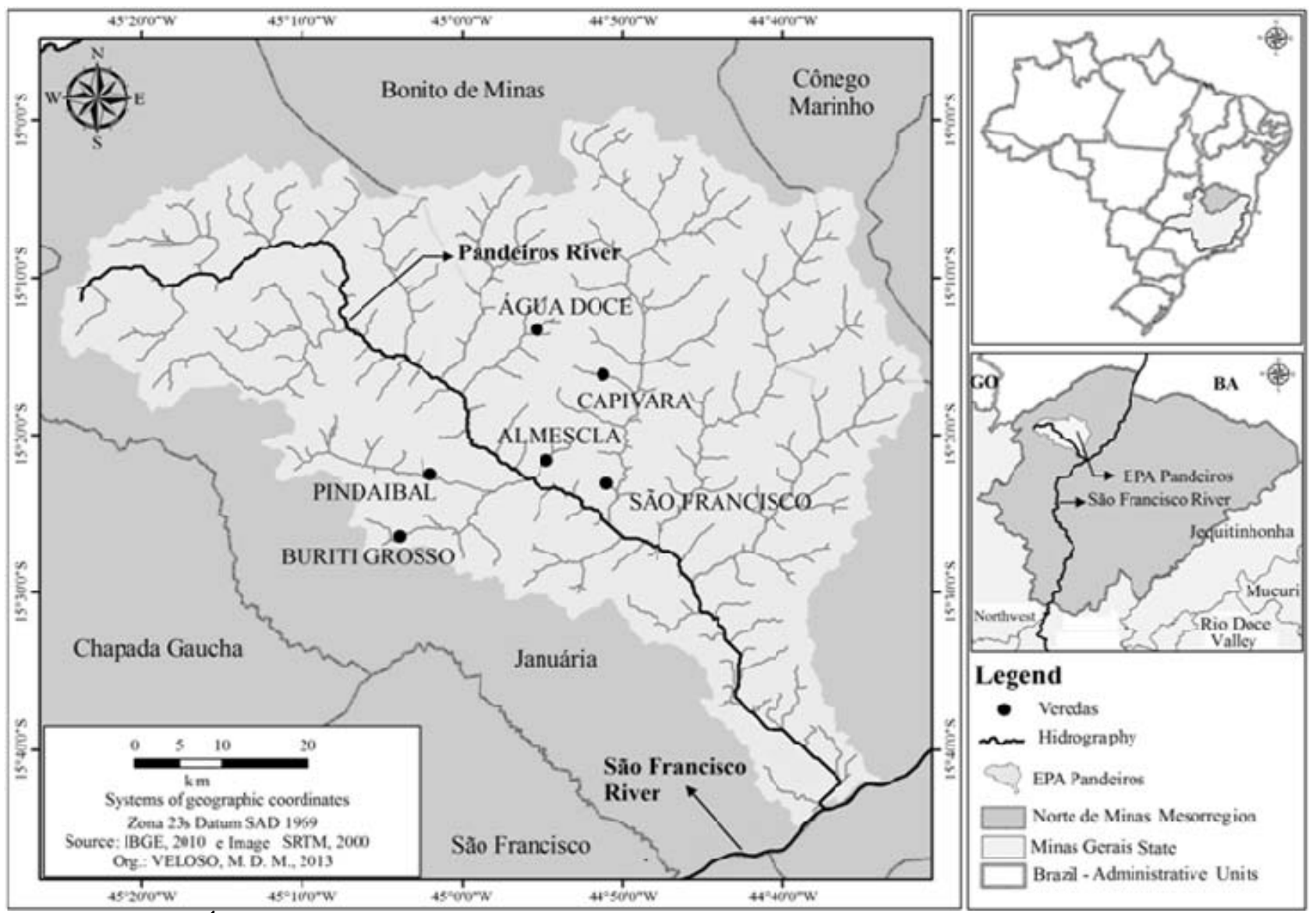

Fig. 1 Location of Água Doce (AD), Almescla (AM), São Francisco (SF), Buriti Grosso (BG), Capivara (CP) and Pindaibal (PI) palm swamps areas at the environmental protection area (EPA) of Pandeiros river in Northern Minas Gerais state, Brazil.

dense, with an average height of $25 \mathrm{~m}$, and there are no artificial gutters. There is evidence of cattle and the selective chopping of individual trees. At the AM palm swamp, the occurrence of water is also steady throughout the year and trees are dense and tall (average $30 \mathrm{~m}$ ), but there is evidence of past fires, ditches and cattle. The palm swamp SF is a private reserve of natural heritage surrounded by fences and protected from anthropic action. In this area, water is present year-round and vegetation at the bottom of the palm swamp reaches an average height of $25 \mathrm{~m}$.

At BG palm swamp area, trees are sparse, with an average height of $8 \mathrm{~m}$, and water is present only at the gutter (water channel) during the rainy season. There is evidence of artificial water drainage across the longitudinal direction of the palm swamp as well as evidence of cattle and fire. At CP, the sparse trees reach an average height of $15 \mathrm{~m}$, there is no gutter for water flow, and water is stored at the soil surface only during the rainy season. In this area, there are artificial drains, agriculture activity, numerous livestock and records of large fires. At PI palm swamp area, the trees are sparse, with an average height of $15 \mathrm{~m}$. The water channel has water all year, but the livestock and small agriculture, as well as fire damage, are present not only at the grassy stratum in the middle of the palm swamp but also at the arboreal stratum deep inside the palm swamp area.

The characterization of soil attributes was performed using composed samples, collected from a layer $0-20 \mathrm{~cm}$ deep from the interior of $100 \mathrm{~m}^{2}$ areas $(10 \mathrm{~m} \times 10 \mathrm{~m})$ that had previously been used for arboreal vegetation sampling [8]. After collection, the soil samples were dried in open air, passed through 2 
$\mathrm{mm}$ sieves and analyzed according to the methodology proposed by Embrapa [14]. Ca and $\mathrm{Mg}$ content were determined by atomic absorption spectrophotometry. Potassium (K) was determined by flame photometry and phosphorus $(\mathrm{P})$ by colorimetry. The sum of bases (SB), cation exchange capacity at pH 7 (CECpH7), effective cationic exchange capacity (CECe), base saturation (V\%) and aluminum (Al) saturation $(\mathrm{m} \%)$ were calculated. The $\mathrm{pH}$ was determined, and the remaining $\mathrm{P}$ (Prem) was analyzed using anionic change resin. A determination of soil organic matter (SOM) was performed using humid oxidation with potassium dichromate in a hot sulfurous environment. The excess dichromate was titrated with a standard ferrous ammonium sulfate solution (Mohr's salt) according to Embrapa [14]. Granulometric analysis to determine the proportion of sand, silt and clay was performed using the pipette method based on Stokes' law for the sedimentation of particles with a solution of sodium hexametaphosphate, buffered with sodium carbonate, for the total dispersion of particles.

The data analysis of soil attributes was performed using Statistica 10 software [15], with the generalized linear model (GLM) of ANOVA procedure [16, 17]. The soil chemical attributes were interpreted according to Alvarez et al. [18]. To verify similarities between the six palm swamps evaluated areas, sensitivity analysis with R were used [19].

\section{Results and Discussion}

The soil chemical attributes were different among the evaluated areas, but the soil texture was similar (Table 1). Regarding the classification of the soil attributes (Figs. 2a-2m), according to Alvarez et al. [18], the AD palm swamp presented lower rates of $\mathrm{pH}, \mathrm{Al}, \mathrm{H}+\mathrm{Al}$ and $\mathrm{m}$ (Figs. 2a-2c and $2 \mathrm{j}$ ) and highest rates of $\mathrm{Ca}, \mathrm{SB}$, CECe, CECpH7, V\% and SOM (Figs. 2e, 2h, 2i, $2 \mathrm{k}-2 \mathrm{~m}$ ), compared to the other palm swamps soils studied. The higher soil fertility at AD palm swamp may be attributed to the raw material composed to calcareous rock outcroppings upstream of this area that contribute

Table 1 Soil chemical and physical attributes (mean and standard deviation) at Água Doce (AD), Almescla (AM), Buriti Grosso (BG), Capivara (CP), Pindaibal (PI) and São Francisco (SF) the palm swamps areas located at the environmental protection area (EPA) of Pandeiros river in Northern Minas Gerais state, Brazil..

\begin{tabular}{lllllll}
\hline \multirow{2}{*}{ Attributes } & \multicolumn{5}{c}{ Palm swamps } \\
\cline { 2 - 7 } & AD & AM & BG & CP & PI & SF \\
\hline pH & $6.77 \pm 0.043$ & $5.33 \pm 0.043$ & $4.93 \pm 0.043$ & $4.96 \pm 0.043$ & $6.27 \pm 0.043$ & $5.70 \pm 0.043$ \\
$\mathrm{P}$ & $15.92 \pm 1.156$ & $2.63 \pm 1.162$ & $10.74 \pm 1.162$ & $37.88 \pm 1.162$ & $17.67 \pm 1.162$ & $6.75 \pm 1.162$ \\
Prem & $33.67 \pm 0.695$ & $18.81 \pm 0.698$ & $24.52 \pm 0.698$ & $14.3 \pm 0.698$ & $26.49 \pm 0.698$ & $32.51 \pm 0.698$ \\
$\mathrm{~K}$ & $143.44 \pm 7.664$ & $148.99 \pm 7.703$ & $19.14 \pm 7.703$ & $20.32 \pm 7.703$ & $58.06 \pm 7.703$ & $69.20 \pm 7.703$ \\
$\mathrm{Ca}$ & $14.2 \pm 0.293$ & $4.33 \pm 0.294$ & $0.57 \pm 0.294$ & $0.81 \pm 0.294$ & $6.06 \pm 0.294$ & $5.24 \pm 0.294$ \\
$\mathrm{Mg}$ & $1.82 \pm 0.068$ & $1.25 \pm 0.068$ & $0.28 \pm 0.068$ & $0.41 \pm 0.068$ & $2.47 \pm 0.068$ & $1.21 \pm 0.068$ \\
$\mathrm{Al}$ & $0.01 \pm 0.105$ & $0.52 \pm 0.105$ & $1.92 \pm 0.105$ & $1.27 \pm 0.105$ & $0.10 \pm 0.105$ & $0.12 \pm 0.105$ \\
$\mathrm{H}+\mathrm{Al}$ & $1.38 \pm 0.334$ & $6.82 \pm 0.336$ & $11.5 \pm 0.336$ & $9.70 \pm 0.336$ & $4.26 \pm 0.336$ & $3.48 \pm 0.336$ \\
$\mathrm{SB}$ & $16.289 \pm 0.343$ & $5.97 \pm 0.345$ & $0.9 \pm 0.345$ & $1.26 \pm 0.345$ & $8.68 \pm 0.345$ & $6.63 \pm 0.345$ \\
$\mathrm{CECe}$ & $16.29 \pm 0.346$ & $6.49 \pm 0.348$ & $2.82 \pm 0.348$ & $2.53 \pm 0.348$ & $8.77 \pm 0.348$ & $6.75 \pm 0.348$ \\
$\mathrm{~m} \%$ & $0.03 \pm 1.512$ & $13.09 \pm 1.520$ & $62.08 \pm 1.520$ & $51.18 \pm 1.520$ & $1.96 \pm 1.520$ & $3.36 \pm 1.520$ \\
$\mathrm{CECpH} 7$ & $17.67 \pm 0.427$ & $12.79 \pm 0.429$ & $12.4 \pm 0.429$ & $10.96 \pm 0.429$ & $12.94 \pm 0.429$ & $10.11 \pm 0.429$ \\
V\% & $91.49 \pm 1.402$ & $45.1 \pm 1.409$ & $9.59 \pm 1.409$ & $11.96 \pm 1.409$ & $67.30 \pm 1.409$ & $63.46 \pm 1.409$ \\
SOM & $14.86 \pm 0.317$ & $12.2 \pm 0.319$ & $11.32 \pm 0.319$ & $10.65 \pm 0.319$ & $11.42 \pm 0.319$ & $9.24 \pm 0.319$ \\
Sand & $85.48 \pm 1.13$ & $78.73 \pm 1.197$ & $81.33 \pm 1.196$ & $76.59 \pm 1.197$ & $77.92 \pm 1.197$ & $79.39 \pm 1.197$ \\
Silt & $8.54 \pm 0.446$ & $11.52 \pm 0.448$ & $10.66 \pm 0.448$ & $8.75 \pm 0.448$ & $11.98 \pm 0.448$ & $10.75 \pm 0.448$ \\
Clay & $5.98 \pm 0.327$ & $9.76 \pm 0.329$ & $6.87 \pm 0.329$ & $14.67 \pm 0.329$ & $10.10 \pm 0.329$ & $9.86 \pm 0.329$ \\
\hline Prem: & &
\end{tabular}

Prem: remaining P; H + Al: potential acidity; SB: sum of bases; CECe: effective cationic exchange capacity; $\mathrm{m} \%$ : Al saturation; $\mathrm{CECpH7}$ : cation exchange capacity at $\mathrm{pH} 7$; $\%$ : base saturation; SOM: soil organic matter. 


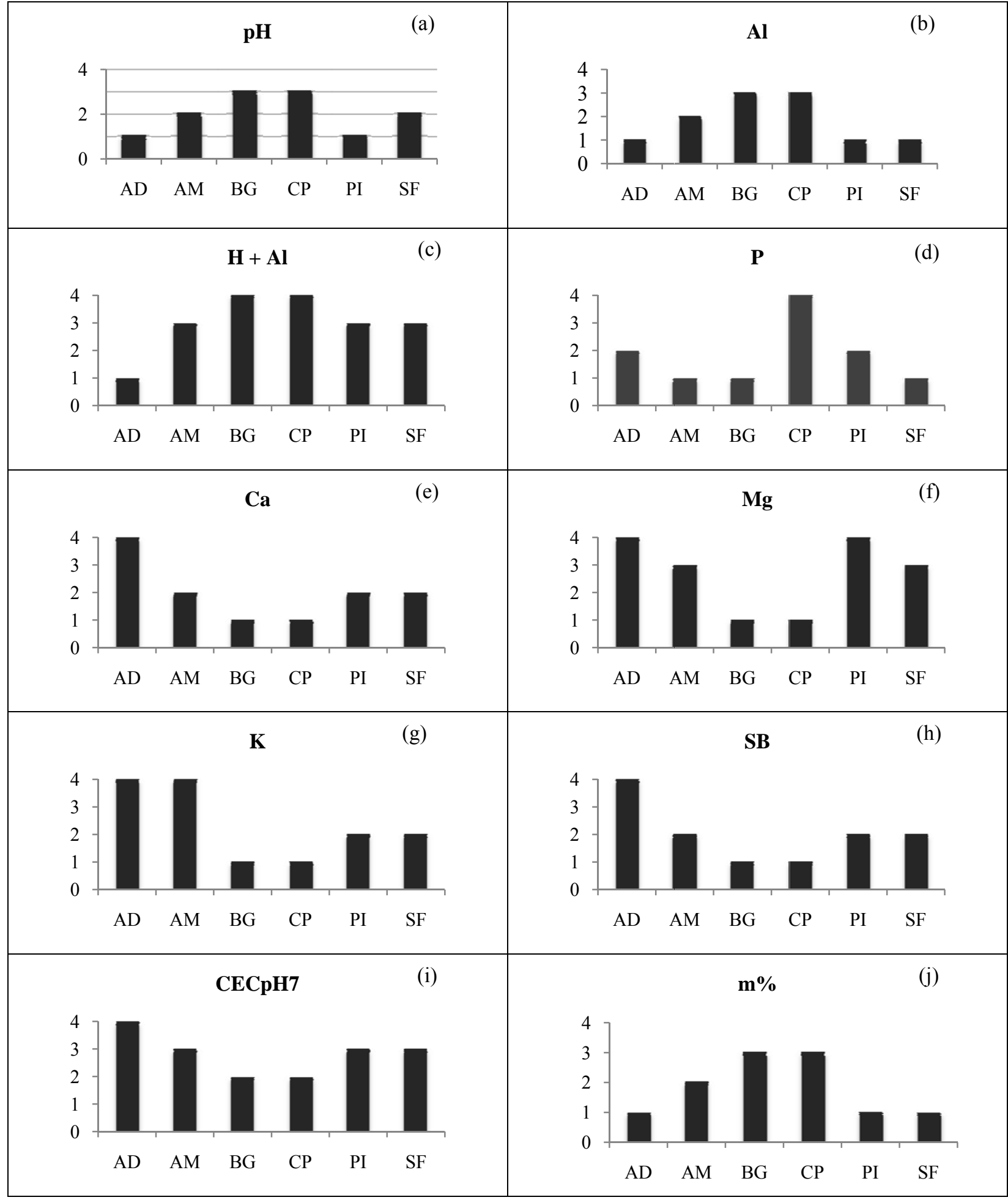




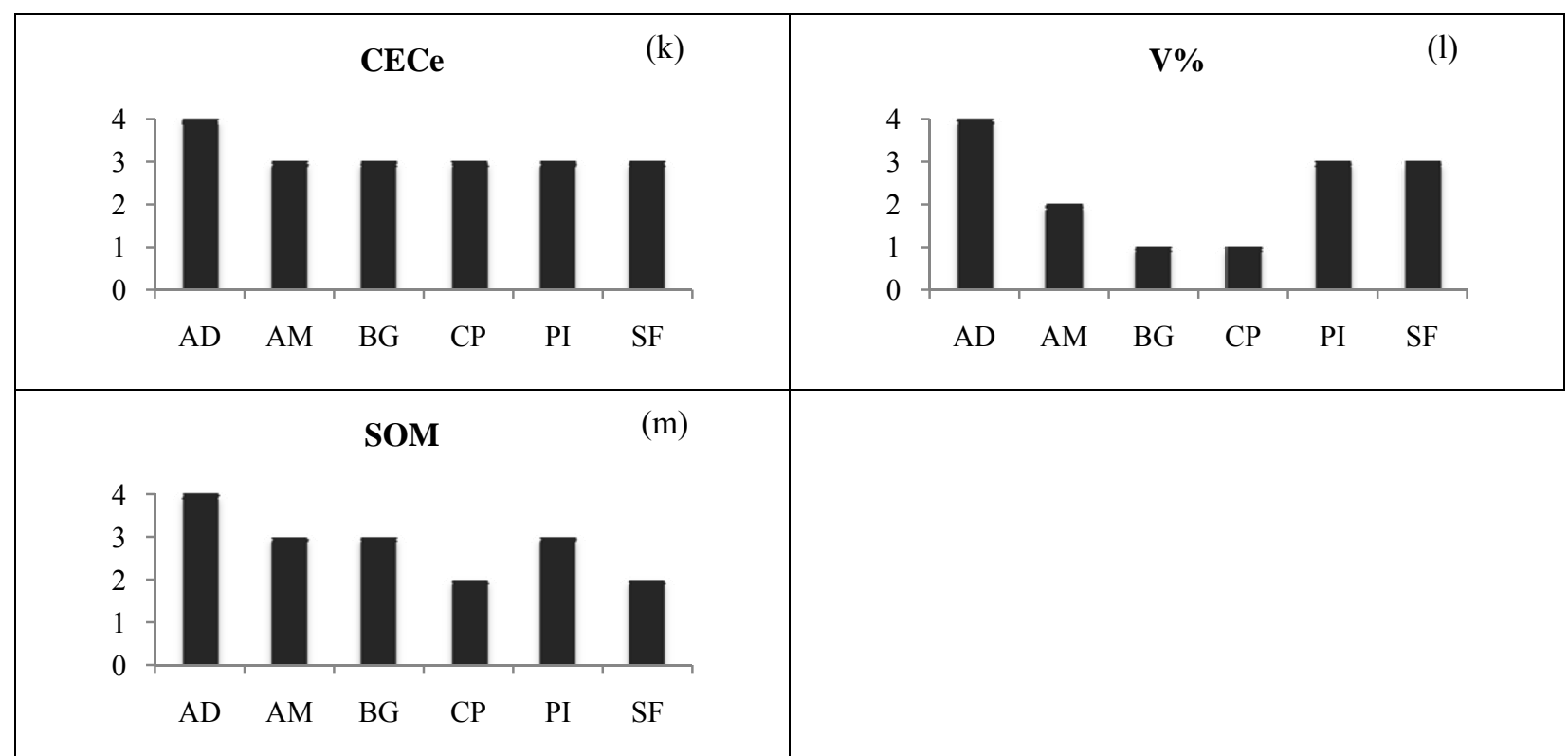

Fig. 2 Soil attribute classification (1: low; 2: medium; 3: high; 4: very high) at AD, AM, BG, CP, PI and SF palm swamps areas located at EPA of Pandeiros river in Northern Minas Gerais state, Brazil.

to nutrient rates and acidity neutralization. This explains the higher production of aerial phytomass at this palm swamp area, as observed by Nunes et al. [5].

According to the survey of regenerating strata of vegetation published by Ávila et al. [20], the AD palm swamp showed the highest richness and abundance compared to the other studied areas. This higher biomass production can be attributed to natural soil fertility. In contrast, vegetation may have contributed to higher values of CECe and SOM in this palm swamp (Figs. $2 \mathrm{k}$ and $2 \mathrm{~m}$ ). Moreover, areas with higher soil fertility are those that present higher density, richness and abundance of vegetal species.

In contrast to the palm swamps of $\mathrm{AD}$ and $\mathrm{SF}$, the remaining palm swamps did not contain rocky outcroppings, which can reduce soil fertility. Beyond the differentiation of source material, the lower soil fertility at the remaining palm swamps may be attributed to hydric erosion resulting from deforestation of the surrounding areas. At BG, CP and PI palm swamps, laminar and groove erosion were visible and contributed significantly to the removal of the most fertile soil layers. In soils of BG and $\mathrm{CP}$ palm swamps these results were confirmed by low SB,
CECe and V (\%) rates (Figs. 2h, 2k and 2l) that makes establishment of large vegetation difficult and consequently leads to a lower contribution of residual vegetation in the soil [9].

The attributes related to soil quality are influenced by land use and soil management, mainly at the surface layers [21]. Neves [13] reported that in the 1980s, native vegetation at BG, PI and CP was replaced by a monoculture of rice, and the surrounding vegetation was replaced by eucalyptus plantations. Nunes et al. [5] and Ávila et al. [20] observed in phytosociological analysis at the six studied palm swamps that AD shows the highest richness, abundance and base area, both in the arboreal strata and the regenerating stratum compared to BG, $\mathrm{CP}$ and PI palm swamps. Therefore, reduction in vegetal biomass may be attributed, among other factors, to excessive land use, given that in these areas, the anthropic processes are reflected in the analysis (Table 1) and in regional records.

Erosion resulting from use and handling at the neighboring areas certainly contributes negatively to soil fertility and vegetation establishment. The greater vegetation observed at $\mathrm{AM}$ and $\mathrm{SF}$ over $\mathrm{BG}, \mathrm{CP}$ and PI palm swamps probably occurs due to the adequate 
land use and soil management in surrounding areas (considered palm swamps recharge areas) as well as their current conservation condition despite long periods of intensive soil use [13].

In the current study, the palm swamp of PI exhibits greater soil fertility recovery (SB, CECe and V (\%)) when compared to the BG and CP palm swamps (Figs. $2 \mathrm{~h}, 2 \mathrm{i}$ and $2 \mathrm{l})$. These results can be attributed to small portions of these palm swamps are still in good conservation condition; some sampled areas of PI were highly impacted but others are preserved. At the palm swamps of $\mathrm{BG}$ and $\mathrm{CP}$, degradation processes are observed across the entire palm swamp.

Vegetal community structure is directly related to habitat physical characteristics, and variations at the substrate mainly humidity, fertility and topography influence the distribution of arboreal species [22]. Locations with higher soil nutrient rates shelter vegetation with higher base area, density and species relative dominance [1]. The lower soil fertility caused by erosive processes contributes to a reduced cover of native vegetation, as identified at $\mathrm{BG}, \mathrm{CP}$ and part of PI palm swamps. The lowering of the water table, aggravated by anthropization in humid areas, provides conditions for the invasion of Cerrado colonizer woody species [23].
In contrast, according to the soil chemical analysis, $\mathrm{AD}, \mathrm{AM}$ and $\mathrm{SF}$ palm swamps are in good conservation condition (Table 1). These data explain the values acquired through surveys of vegetation made at these six palm swamps areas $[5,20]$ which showed high values of richness, abundance and base area, among other parameters, both at the arboreal strata and on the regenerating stratum, when compared to the results BG, CP and PI palm swamps areas.

Using the similarity or dissimilarity between areas, a dendrogram was constructed from the soil attribute means at the six palm swamps areas, which demonstrates clustering into three different groups. The most impacted palm swamps areas, BG and CP formed a distinct group that distanced itself from the others. PI and SF formed a second group, and AD and $\mathrm{AM}$, the most preserved palm swamps areas, formed the third group (Fig. 3). By comparing the observations of these areas with the results shown here, it may be inferred that the aggregation used to form these groups confirms the current condition of these palm swamps areas. These results are in agreement with those by Araújo et al. [24] in studies made in other palm swamps areas, where similarity was evaluated using soil edaphic characteristics.

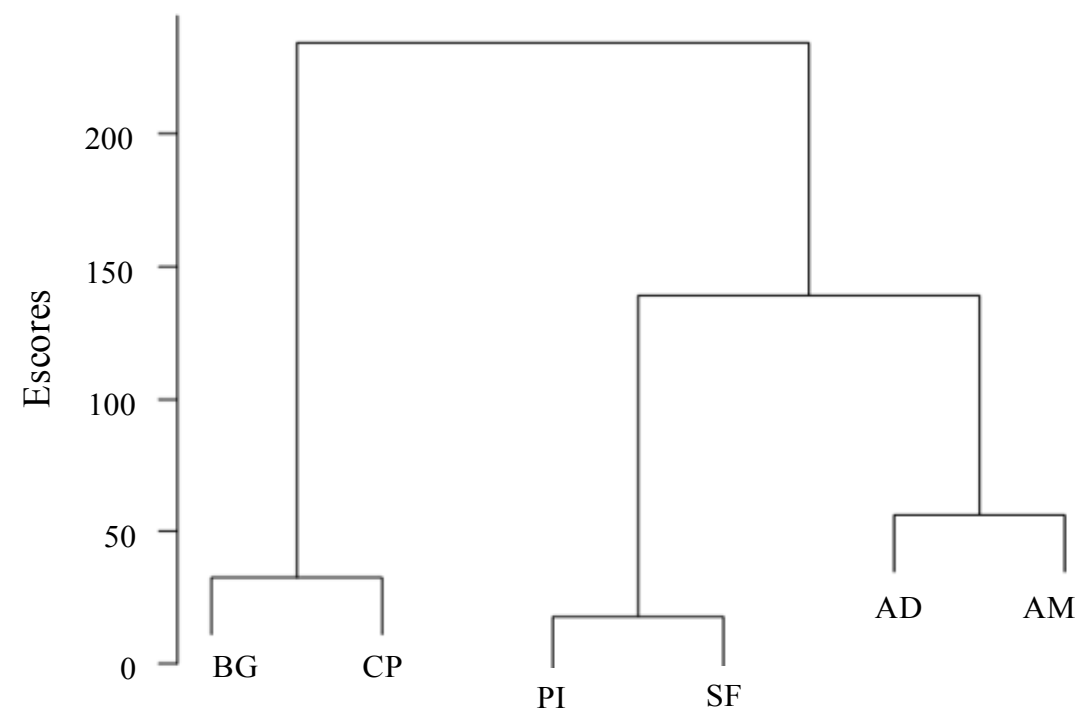

Fig. 3 Similarity dendrogram constructed from the means of soil attributes, evaluated at AD, AM, SF, BG, CP and PI palm swamps areas located at EPA of Pandeiros river in Northern Minas Gerais state, Brazil. 
The palm swamps areas of BG and CP are highly degraded, not only in the presence of vegetal species and visual characteristics but also in relation to soil chemical and physical analysis (Table 1). The second group, which shows a close relationship between the palm swamps PI and SF, may have occurred due to sampling at PI. This area contains both highly preserved territory and highly impacted land such as corn, sugar cane and bean plantations throughout the palm swamp. Therefore, the grouping of palm swamps by PI, which is, on average, considered degraded, with $\mathrm{SF}$, a well-preserved palm swamp, may be due to sampled portions that were better preserved than average PI area. In other words, samples from less impacted areas of PI may have had a greater influence on the dendrogram, since SF is better preserved than PI (local observations), which is still dominated by subsistence agriculture over large area after the abandonment of monoculture and shows evidence of degradation.

The grouping of $\mathrm{AD}$ and $\mathrm{AM}$ palm swamps may be justified by their preservation condition, as both are highly developed arboreal strata that are adapted to hydric saturation as provide habitat for the palm trees Mauritia flexuosa L. f. and Mauritiella armata (Mart.) Burret, typical species of these environments. Soil nutrients and organic matter rates are similar in both palm swamps, indicating common conservation conditions.

\section{Conclusions}

Buriti Grosso and Capivara palm swamps areas that suffered higher anthropic interventions showed reduction in soil fertility. The formation of three similarity groups gives evidence that soil fertility at the surface layer in the evaluated palm swamps is a consequence of the soil raw material, land use and soil management that have occurred for decades in the studied region.

\section{Acknowledgments}

This work is part of the post-doctoral studies of the first author. The authors express their thanks to FAPEMIG (BIPDT: APQ-00227-16; PPM: APQ-00623-16 and PPP: APQ-00468-15) and CNPq/PELD (CNPq 441440/2016-9).

\section{References}

[1] Haridasan, M. 2000. "Mineral Nutrition of Native Plants of Cerrado." Revista Brasileira de Fisiologia Vegetal 1: 54-64. (in Portuguese)

[2] Oliveira, O. S., and Marquis, R. J. 2002. The Cerrados of Brazil: Ecology and Natural History of a Neotropical Savanna. New York: Columbia University Press.

[3] Eiten, G. 1972. "The Cerrado Vegetation of Brazil." The Botanical Review 38 (2): 201-341.

[4] Vendrame, P. R. S., Brito, O. R., Guimares, M. F., Martins, D. S., and Becquer, T. 2010. "Fertility and Acidity Status of Latossolos (Oxisols) under Pasture in the Brazilian Cerrado." Academia Brasileira de Ciências 4: 1085-94.

[5] Nunes, Y. R. F., Bahia, T. O., Ávila, M. A., Veloso, M. D. M., and Santos, R. M. 2015. "Floristic and Phytosociology of the Veredas Tree Communities: A Case Study in Northern Minas Gerais, Brazil." In Phytosociology of Brazil: Methods and Case Studies, edited by Elsenlohr, P. V., Fagg, C. W., Melo, M. M. R. F., Andrade, J. A., and Meira Neto, J. A. A. Viçosa: Editora Viçosa, 264-87. (in Portuguese)

[6] Boaventura, R. S. 2007. Veredas: Cradle of Waters. Belo Horizonte: Ecodinâmica. (in Portuguese)

[7] Tubelis, D. P. 2009. "Veredas and Their Use by Birds in the Cerrado, South América: A Review." Biota Neotropica 3: 363-74.

[8] Bahia, T. O., Luz, G. R., Veloso, M. D. M., Nunes, Y. R. F., Neves, W. V., Braga, L. L., and Lima, P. C. V. 2009. Veredas in the APA of Rio Pandeiros: Importance, Environmental Impacts and Perspectives. MG. Biota. Belo Horizonte: Insituto Estadual de Florestas, 4-13. (in Portuguese)

[9] Santos, A. C., and Salcedo, I. H. 2010. "Fertility in the Várzea and Topo Areas due to the Use of the Soil and the Position of the Relief." Revista de Biologia e Ciências da Terra 2: 83-90. (in Portuguese)

[10] Galvão, S. R. S., Salcedo, I. H., and Santos, A. C. 2005. "Carbon and Nitrogen Fractions as a Function of Texture, Relief and Soil Use in the Agave Microbasin in Vaca Brava (PB)." Revista Brasileira de Ciência do Solo 4: 955-62. (in Portuguese)

[11] Carvalho, J. L. N., Cerri, C. E. P., Cerri, C. C., Feigl, B. J., Piccolo, M. C., Godinho, V. P., and Herpin, U. 2007. "Changes of Chemical Properties in an Oxisol after 
Clearing of Native Cerrado Vegetation for Agricultural Use in Vilhena, Rondonia State, Brazil." Soil and Tillage Research 96: 95-102.

[12] Perin, E., Ceretta, C. A., and Klamt, E. 2003. "Time of Agricultural Use and Chemical Properties of Two Latosols of the Middle Plateau of Rio Grande do Sul." Revista Brasileira de Ciência do Solo 27: 665-74. (in Portuguese)

[13] Neves, W. V. 2011. "Evaluation of the Flow in Watersheds with Veredas in Different Stages of Conservation in the APA of Rio Pandeiros-MG." Dissertation, Federal University of Minas Gerais. (in Portuguese)

[14] Embrapa. 1997. Manual of Soil Analysis Methods, 2nd editon. National Soil Research Center, Rio de Janeiro, 212. (In Portuguese)

[15] Statsoft. 2011. Statistica (data analysis software system). V. 10. www.statsoft.com.

[16] Nelder, J. A., and Wedderburn, W. M. 1972. "Generalized Linear Models." Journal of the Royal Statistical Society 135 (3): 370-84.

[17] Zar, J. H. 1996. Biostatistical Analysis. New Jersey: Prentice-Hall, Englewood Cliffs.

[18] Alvarez, V. H., Novais, R. F., Barros, N. F., Cantarutti, R. B., and Lopes, A. S. 1999. "Interpretation of Soil Analysis Results." In Recommendations for the Use of Correctives and Fertilizers in Minas Gerais. Ribeiro, A. C., Guimarães, P. T. G., and Alvarez, V. H. (eds.) Viçosa, 25-32. (in Portuguese)

[19] Husson, F., Sebastien, L., Cadoret, M., and Mine, R. S. 2012. "Sensory Data Analysis with R." R package v. 1.20.
Accessed October 12, 2017. https://CRAN.R-project.org/ pakage $=$ SensoMineR.

[20] Ávila, M. A., Souza, S. R., Veloso, M. D. M., Santos, R. M., Fernandes, L. A., and Nunes, Y. R. F. 2016. "Structure of Natural Regeneration in Relation to Soil Properties and Disturbance in Two Swamp Forests." Cerne 1: 1-10.

[21] Negreiros, D., Fernandes, G. W., Berbara, R. L. L., Rodarte, L. H. O., and Ulhôa, N. P. 2012. "Physicochemical Characterization of Quartzitic Degraded Soils and Adjacent Areas of Rupestrian Fields, Serra do Cipó, MG, Brazil." Neotropical Biology and Conservation 3: 156-61.

[22] Oliveira-Filho, A. T., Vilela, E. A., Carvalho, D. A., and Gavilanes, M. L. 1994. "Effects of Soils and Topography on the Distribution of Tree Species in a Tropical Riverine Forest in South-Eastern Brazil." Journal of Tropical Ecology 10: 483-508.

[23] Meirelles, M. L., Oliveira, R. C., Vivaldi, L. J., Santos, A. R., and Correia, J. R. 2002. "Species of the Herbaceous Stratum and Depth of the Water Table in Humid Areas of the Cerrado." Research and Development Bulletin. Planaltina: Embrapa Cerrados. Accessed November 15, 2017. https://www.infoteca.cnptia.embrapa.br/bitstream/ doc/548509/1/bolpd25.pdf. (in Portuguese)

[24] Araújo, G. M., Barbosa, A. A. A., Arantes, A. A., and Amaral, A. F. 2002. "Floristic Composition of Trails in the City of Uberlândia, MG." Revista Brasileira de Botânica 4: 475-93. (in Portuguese) 